\title{
Large-scale assessment of regeneration and diversity in Mediterranean planted pine forests along ecological gradients
}

\author{
Paloma Ruiz-Benito Lorena Gómez-Aparicio and Miguel A. Zavala
}

\begin{abstract}
Aim There is increasing concern regarding sustainable management and restoration of planted forests, particularly in the Mediterranean Basin where pine species have been widely used. The aim of this study was to analyse the environmental and structural characteristics of Mediterranean planted pine forests in relation to natural pine forests. Specifically, we assessed recruitment and woody species richness along climatic, structural and perturbation gradients to aid in developing restoration guidelines.
\end{abstract}

Location Continental Spain.

Methods We conducted a multivariate comparison of ecological characteristics in planted and natural stands of main Iberian native pine species (Pinus halepensis, Pinus pinea, Pinus pinaster, Pinus nigra and Pinus sylvestris). We fitted species-specific statistical models of recruitment and woody species richness and analysed the response of natural and planted stands along ecological gradients.

Results Planted pine forests occurred on average on poorer soils and experienced higher anthropic disturbance rates (fire frequency and anthropic mortality) than natural pine forests. Planted pine forests had lower regeneration and diversity levels than natural pine forests, and these differences were more pronounced in mountain pine stands. The largest differences in recruitment - chiefly oak seedling abundance - and species richness between planted and natural stands occurred at low-medium values of annual precipitation, stand tree density, distance to Quercus forests and fire frequency, whereas differences usually disappeared in the upper part of the gradients.

Main conclusions Structural characteristics and patterns of recruitment and species richness differ in pine planted forests compared to natural pine ecosystems in the Mediterranean, especially for mountain pines. However, management options exist that would reduce differences between these forest types, where restoration towards more natural conditions is feasible. To increase recruitment and diversity, vertical and horizontal heterogeneity could be promoted by thinning in high-density and homogeneous stands, while enrichment planting would be desirable in mesic and medium-density planted forests.

\section{Keywords}

Continental Spain, management, naturalization, plantation, recruitment limitation, woody species richness.

\section{INTRODUCTION}

Forests cover more than $30 \%$ of the terrestrial biosphere (FAO, 2010) and harbour around two-thirds of terrestrial biological diversity (MEA, 2005). These reservoirs of biodiversity are threatened by ongoing deforestation and forest degradation processes (FAO, 2010), and increasingly also by new pressures such as climatic change (Dale et al., 2001). Restoration is a promising approach to counteract loss of forests and related ecosystem services (Lamb et al., 2005; Chazdon, 2008). 
Restoration activities focus on contrasting but complementary strategies, namely 'passive restoration' or forest regrowth based on secondary succession and 'active restoration' or tree plantations (Mansourian, 2005). World-wide afforestations have reforested more land than forest regrowth during the period 2000-10 (4.9 vs. 2.9 million ha $\mathrm{yr}^{-1}$, respectively, FAO 2010). Tree planting on deforested land is a rapid recovery strategy that may increase both diversity and provisioning of ecosystem services (Rey Benayas et al., 2009).

In general, planted forests have chiefly been used in the past for timber and fibre production, but also serve protective (e.g. soil erosion mitigation or basin conservation) and/or recreational purposes (FAO, 2006; Evans, 2009). Currently, there is an increasing demand for multipurpose tree plantations (Paquette \& Messier, 2010) because of policies addressing wood supply (Sutton, 1999), restoration of abandoned farmland (Rey Benayas, 2005) and carbon sequestration (Jackson et al., 2005; Canadell \& Raupach, 2008), which has led to an increase in the planted forest surface (FAO, 2010). World-wide planted forests, however, are highly controversial, and plantations are often considered as 'green deserts' (Stephens \& Wagner, 2007; Bremer \& Farley, 2010; Felton et al., 2010) or 'novel ecosystems' (e.g. Hobbs et al., 2006) that do not completely achieve the ecosystem services provided by natural forests (Rey Benayas et al., 2009). Furthermore, some authors have highlighted trade-offs between ecosystem services provided by tree plantations (e.g. carbon sequestration versus soil water availability, Jackson et al., 2005). Thus, there is an urgent need for planted forests to act as sustainable systems that meet standards similar to those of natural forests in terms of biodiversity conservation and ecosystem functioning (Evans, 2009; Bremer \& Farley, 2010). Although a number of studies have compared the structure and function of plantations and paired natural forests (e.g. Lugo, 1992; Gómez-Aparicio et al., 2009), a few have examined both forest types across extensive regions.

The Mediterranean Basin is one of the world regions with the largest proportion of planted forests (FAO, 2010). Largescale afforestation programs were initiated in the late 19th century to restore degraded lands after thousands of years of human exploitation (Barbero et al., 1998). The Spanish Reforestation Plan of 1939 is a good example of such largescale reforestations, because it involved around 3.5 million ha of planted forests from 1940 to 1995 (Montero, 1997). Pines were the most commonly used tree species because of their fast growing pioneer performance, providing rapid ground coverage and eventually facilitating establishment of late successional hardwoods (Zavala \& Zea, 2004). However, the achievements of these afforestation policies have often been questioned. For example, the lack of post-plantation operations - because of elevated costs and low timber production (Madrigal, 1998) - has often resulted in high-density stands with arrested succession (i.e. lack of pine replacement by later successional species such as hardwoods, Chirino et al., 2006). Secondary succession may also be impeded in planted pine forests because of low seed supply (García et al., 2010) as avian diversity and seed disperser preferences are negatively influ- enced by a simplified forest structure (López \& Moro, 1997) and its surrounding vegetation (Zamora et al., 2010). As a result, planted forests may exhibit poorer regeneration and lower species richness than adjacent natural forests (GómezAparicio et al., 2009).

After more than 60 years of the massive Spanish afforestation effort, the characteristics of these planted pine forests and their consequences for key functional and structural attributes of the forest community, such as recruitment and species diversity, remain largely unexplored. We addressed the following objectives: (1) to identify differences between planted and natural pine forests, particularly those regarding edapho-climatic conditions, structural features and disturbance regimes; (2) to assess patterns of pine and oak recruitment and woody species richness in both ecosystems - planted and natural - along climatic, vegetation structure and disturbance gradients; and (3) to propose specific management and restoration recommendations intended to reduce differences between planted forests and natural pine forests. These objectives, based on a comparison of planted forests versus reference natural systems (Dudley, 2005), will enable us to generate valuable theoretical and practical information on diversity and succession in Mediterranean pine plantations.

\section{METHODS}

\section{Study area and data set}

The Iberian Peninsula presents a wide altitudinal range (sea level-3500 m) and a steep climatic gradient - from arid Mediterranean to cool temperate climates - all of which confers this region with high habitat and species diversity. Pine forests constitute a structural component of Mediterranean plant communities and spatially, they may coexist with, alternate with or be segregated from hardwoods (Blanco et al., 1997). Pine forests can be the successional end point under severe environmental conditions, such as dry or cold climates or shallow and rocky soils (Barbero et al., 1998; Zavala et al., 2000).

We built a spatial database by combining three types of data sources: the Spanish Forest Inventory (SFI hereafter), the Spanish Regions of Provenance for Forest Species (SRP hereafter) and several cartographic sources at national scale. We used permanent stands that had been surveyed for the second (1986-96, 2SFI hereafter) and the third SFI (19972007, 3SFI hereafter) and that were distributed over forest ecosystems on a $1-\mathrm{km}^{2}$ cell grid (Villaescusa \& Díaz, 1998). Each SFI stand included four concentric circular sub-plots of 5, 10,15 and $25 \mathrm{~m}$ radius. In these sub-plots, an adult tree was sampled if its diameter at breast height (d.b.h.) was 7.5-12.4, $12.5-22.4,22.5-42.5$ and $\geq 42.5 \mathrm{~cm}$, respectively. Height, d.b.h. and species name were recorded for each adult tree included in the stand.

The SRP was ascertained for each species according to historical information regarding planted versus natural origin (Ceballos, 1966), which was later refined by genetic analyses 
and other regional information (Alía et al., 2009). Our definition of 'natural pine forests' was based on SRP autochthonous forests, that is, a forest originated by natural regeneration from local or nearby native sources (Alía et al., 2005). 'Natural pine forests' in this study excluded all forests planted during the 20th century and included all forests established through natural regeneration (FAO, 2006).

The spatial vector database of the SRP for pine species and the UTM coordinates of the SFI stands were combined using ARCGIS 9.2 (ESRI Inc., Redlands, CA, USA). Where the same adult tree species was observed in the SRP and the SFI, the stand was included in this study. A total of 32,719 stands were selected with the presence of the adult species Pinus halepensis Mill., Pinus pinea L., Pinus pinaster Ait., Pinus nigra Arnold., and Pinus sylvestris L. (Fig. 1). We did not consider P. uncinata Mill., because $99 \%$ of the stands were natural, nor $P$. radiata D. Don, because all stands were planted. About $65.8 \%$ of the pine stands were monospecific and the remaining $34.2 \%$ were mixed stands.

\section{Analysed variables}

Each of the 32,719 stands was characterized by 26 abiotic, six biotic and four anthropic variables. The abiotic variables included four topographic, 19 climatic and three edaphic variables. The topographic variables included altitude $(\mathrm{m})$, slope (degrees), aspect (degrees) and insolation (hours per year) and were calculated from a SRTM V1 digital elevation model with a $1-\mathrm{km}^{2}$ spatial resolution (Shuttle Radar Topographic Mission, http://www2.jpl.nasa.gov/srtm/). The climatic variables, calculated from Gonzalo's (2008) map with a 1-km² spatial resolution, were annual precipitation $(\mathrm{mm})$, seasonal precipitation (i.e. in spring, summer, fall and winter), mean annual temperature $\left({ }^{\circ} \mathrm{C}\right)$, seasonal temperature $\left({ }^{\circ} \mathrm{C}\right)$, mean temperature of the warmest month $\left({ }^{\circ} \mathrm{C}\right)$, mean minimum temperature of the month with lowest mean annual temperature $\left({ }^{\circ} \mathrm{C}\right)$, annual potential evapotranspiration (Thornthwaite, 1948), annual water surplus ( $\mathrm{mm}$, sum of the positive differences between annual precipitation and potential
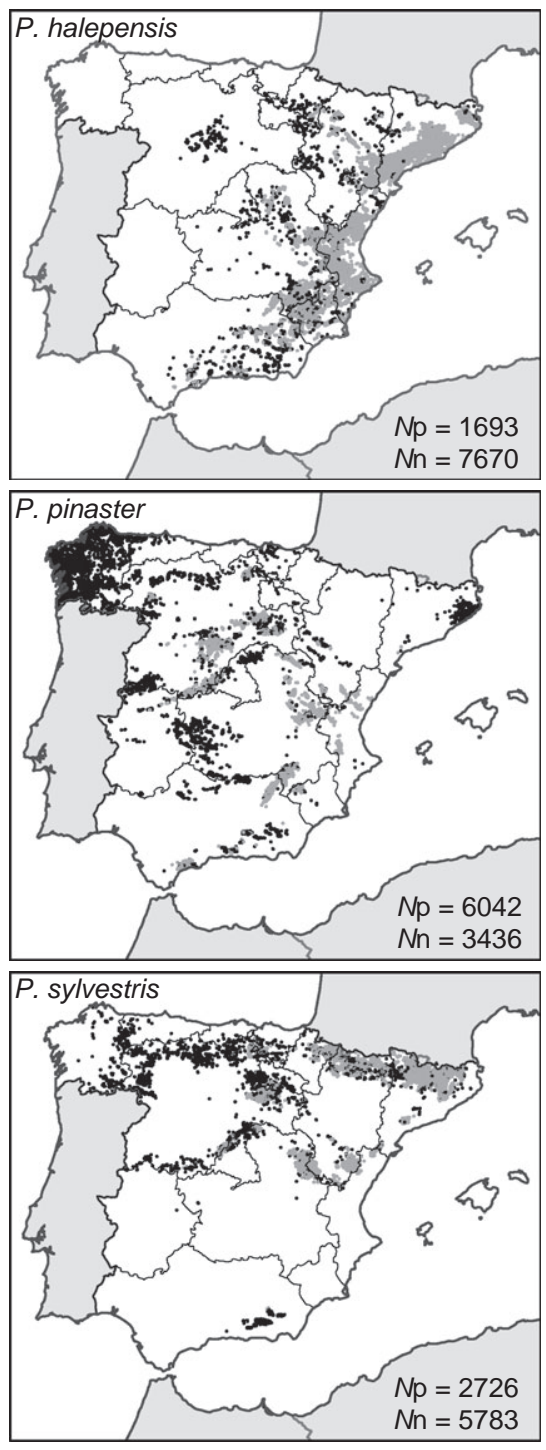
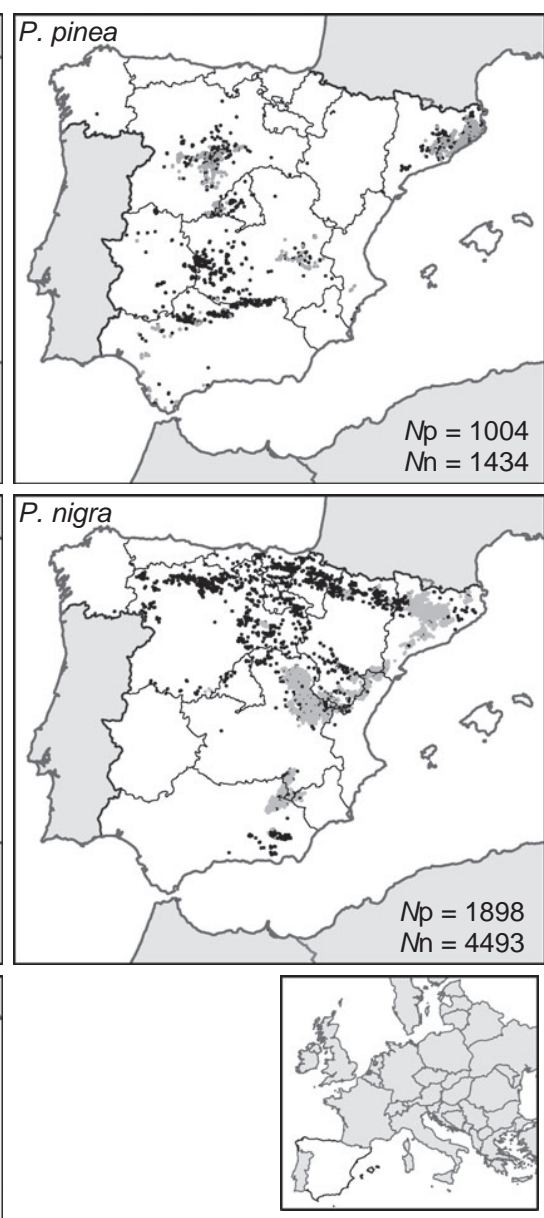

Forest type

Natural stand

Planted stand

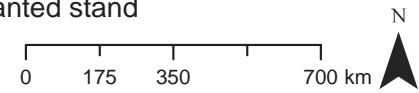

Figure 1 Occurrence of planted (Np) and natural $(\mathrm{Nn})$ pine stands of Pinus halepensis, Pinus pinea, Pinus pinaster, Pinus nigra and Pinus sylvestris included in the study, from the Spanish Forest Inventory. Map projection UTM 30N, European Datum 1950. 
evapotranspiration), annual water deficit ( $\mathrm{mm}$, sum of the negative differences between annual precipitation and potential evapotranspiration), drought length (number of months in which potential evapotranspiration exceeded precipitation) and aridity index (ratio between annual potential evapotranspiration and mean annual precipitation, UNEP, 1997). The relationship between the topographic and climatic variables was explored using Principal Component Analysis in R (R Development Core Team, 2009). The first axis of the PCA (explaining $53.5 \%$ of the variance) was strongly correlated with annual precipitation and the second axis (explaining 21.8\%) with mean annual temperature. Therefore, these two variables were selected for our modelling analysis as being representative of the climatic conditions for each pine stand. The three edaphic variables obtained from 3SFI were rockiness $(0-25 \%, 25-50 \%,>50 \%)$, soil texture (sandy, loam and clay) and soil $\mathrm{pH}($ acid $(\mathrm{pH} \leq 6)$, neutral $(\mathrm{pH}=7)$ or basic $(\mathrm{pH} \geq 8)$ ).

The biotic variables calculated from 3SFI were stand basal area $\left(\mathrm{m}^{2} \mathrm{ha}^{-1}\right)$, stand tree density (No. trees per ha), coefficient of variation of tree diameter (ratio of the standard deviation to the mean of the diameters of all trees in the stand), monospecific character of the stand (ratio of a particular pine species' basal area to total stand basal area), distance to the nearest Quercus forest and natural mortality (basal area in $\mathrm{m}^{2} \mathrm{ha}^{-1}$ of the trees that were present in the 3SFI and had died between the 2SFI and the 3SFI). Distance to the nearest Quercus forest was calculated with ARCGIS 9.2 (ESRI Inc.) as the minimum distance between pine stands of the 3SFI and polygons of the Spanish Forest Map with Quercus presence at scale 1:50,000 (MARM, http://www.marm.es/).

The anthropic variables were anthropic mortality, distance to the nearest road, fire frequency and conservation status. Anthropic mortality was calculated as the basal area $\left(\mathrm{m}^{2} \mathrm{ha}^{-1}\right)$ of the trees that had been removed in the period between the 2SFI and the 3SFI. Distance to the nearest road was calculated from data available at the Spanish Spatial Data Infrastructure portal (IDEE, http://www.idee.es). Fire frequency was calculated for the same survey period between the 2SFI and 3SFI (1986-2007) at municipality level (MARM, http://www.marm.es/). The conservation status was calculated by overlapping the 3SFI stand coordinates with the network of nationally designated natural protected areas (presence/ absence) using ARCGIS 9.2.

The response variables were pine and oak recruitment (number of pine and oak seedlings per stand, respectively) and woody species richness. In the $5-\mathrm{m}$ radius circle of the 3 SFI (area $78.5 \mathrm{~m}^{2}$ ), abundance of seedlings (d.b.h. $<2.5 \mathrm{~cm}$ or height $<1.3 \mathrm{~m}$ ) was quantified using a semi-quantitative scale (low: 1-4 seedlings per ha, medium: $5-15$ seedlings per ha or high: $>15$ seedlings per ha). To transform these data into a continuous scale that could be used in regression analyses, we selected the lowest value of each range as a conservative approach. Woody species richness was calculated as the number of trees and shrub species included in the $25-\mathrm{m}$ radius circular plot of the 3 SFI.

\section{Statistical analyses}

Environmental and structural characteristics of pine forests

We performed three separate analyses to compare the characteristics of planted pine forests and natural pine forests along environmental gradients. Firstly, we used semi-parametric multivariate analyses of variance (PERMANOVA 10,000 permutations; adonis library vegan in $\mathrm{R}$, Oksanen et al., 2010) to examine differences between the two forest types as regards the five abiotic (two climatic and three edaphic), six biotic and four anthropic variables. Secondly, we conducted a Canonical Correspondence Analysis (CCA library vegan in R, Oksanen et al., 2010) to relate pine abundance (estimated as basal area) to the same abiotic, biotic and anthropic variables as those used in the PERMANOVA. Thirdly, the differences for each environmental variable in planted and natural forest stands were identified by means of the Wilcoxon test.

\section{Seedling recruitment patterns}

We examined differences in mean pine and oak seedling abundance between planted and natural forest stands using Wilcoxon tests. Then, we fitted regression models using Generalized Linear Models (GLM) with a negative binomial error distribution and a log link function. A negative binomial distribution was preferred over a Poisson distribution because the response variables showed over-dispersion (Bolker, 2008). The predictor variables included in the models were: forest type (planted versus natural), climatic variables, edaphic factors, biotic variables (distance to the nearest Quercus forest was considered only for Quercus recruitment) and anthropic variables. Continuous variables were included as a linear and second-order polynomial term to select the best transformation of the explanatory variables to account for nonlinearity (Kunstler et al., 2007). First, a step-wise procedure using the Akaike Information Criterion was applied to select the main variables affecting recruitment (stepAIC library MASS in R, Venables \& Ripley, 2002). Then, the interactions between forest type and the variables selected in the previous step were tested to explore whether the effect of a given variable differed between planted and natural forests. The response curves for the explanatory variables were computed between the minimum and maximum values measured in planted and natural stands, with the values of other continuous variables fixed at the mean observed (Table 1), and the most common value for categorical variables.

\section{Woody species richness patterns}

We used the same modelling approach as for seedling recruitment to examine patterns of woody species richness. Firstly, the Wilcoxon test was applied to examine woody species richness differences between planted and natural forests. Secondly, GLM models were run using a Poisson distribution and the log link function to explore variations in species richness along environmental gradients. 


\section{RESULTS}

\section{Environmental and structural characteristics of pine forests}

The characteristics of planted and natural pine forest stands were significantly different for all pine species (PERMANOVA, $F_{P . \text { halepensis }}=55.6, F_{P . \text { pinea }}=109.7, F_{P . \text { pinaster }}=306.8, F_{P . \text { nigra }}=$ 160.2, $F_{P .}$ sylvestris $=27.5, P<0.001$ in all cases).

The first two CCA axes explained $72.6 \%$ of the variation observed in the data, and clearly separated planted from natural stands of the five pine species, especially for $P$. pinaster, P. nigra and P. sylvestris (Fig. 2). The first axis was positively correlated with mean annual temperature and negatively correlated with annual precipitation and stand basal area. These results showed an aridity gradient along axis 1 , where the main differences between planted and natural stands varied strongly depending on the pine species (Fig. 2). P. pinaster and $P$. pinea had higher mean temperature in planted stands than in natural stands, whereas $P$. halepensis and $P$. nigra showed the opposite pattern (Table 1). The second axis of the CCA showed a negative correlation with soil texture, rockiness and $\mathrm{pH}$, and a positive correlation with fire frequency, annual precipitation, stand basal area and anthropic mortality (Fig. 2). These results suggested a gradient along axis 2 where planted forest stands were characterized by higher intensity of disturbance (fire frequency and anthropic mortality) and poorer soils (acid and rocky) than natural forest stands.

Structural characteristics of planted pine forests were in general significantly different from natural pine forests (Table 1). Pine plantations exhibited a higher density and monospecific character, shorter distances to oak forests and a lower coefficient of variation of tree diameter than natural forests.

\section{Seedling recruitment patterns}

Both pine and oak seedling abundance was generally lower in planted than in natural forest stands (Table S1, in Supporting Information). Forest type (planted versus natural) was one of the most explicative variables for pine recruitment (except for $P$. pinea), explaining the largest deviance in the two mountain pines. Climatic variables, biotic variables (mainly tree density or basal area) and anthropic variables (mainly fire frequency) generally explained a high proportion of deviance in the pine recruitment GLM models (Table 2). Forest type was also a significant explanatory factor of oak recruitment in most pine forests (all but $P$. halepensis forests), but it usually explained a lower proportion of deviance than climatic factors, tree density, basal area and distance to the nearest Quercus forest. Anthropic factors also explained a low proportion of the deviance in oak seedling GLM models compared to abiotic and biotic factors (Table 2). A nonlinear response of pine and oak recruitment was observed along all the environmental gradients explored (polynomial transformation of order 2, Table 2). 
Figure 2 Canonical Correspondence Analysis (CCA) of the environmental variables characterizing natural (n.) and planted (p.) forest stands of Pinus halepensis (Pha), Pinus pinea (Ppe), Pinus pinaster (Ppa), Pinus nigra (Pni) and Pinus sylvestris (Psy). Variables with Spearman correlations $>0.3$ are shown on the CCA axes. Confidence ellipses of point scores were included using standard deviation with a confidence interval of $95 \%$.

We detected significant interactions between forest type and several of the abiotic, biotic and anthropic variables for both pine and oak recruitment. The interactions that consistently explained a larger proportion of the deviance across canopy pine species were mainly annual precipitation, tree density, distance to the nearest Quercus forest and fire frequency (Table S2). The largest recruitment differences between forest types generally occurred at intermediate values along the annual precipitation gradient, with lower differences at the extremes of this gradient (Fig. 3a). In Mediterranean pine forests ( $P$. halepensis and $P$. pinaster), the largest recruitment differences between forest types also occurred at intermediate values along the tree density gradient (c. 1000 trees per ha; Fig. 3b). However, oak seedling abundance increased along the tree density gradient in mountain pine stands (Fig. 3b). Distance to the nearest Quercus forest had a negative effect on oak seedling abundance in all pine stands except those of P. sylvestris. The detrimental effect of this variable on oak recruitment was more pronounced in natural than in planted pine stands ( $P$. pinaster and P. nigra; Table S2; Fig. 3c). Fire frequency had an overall negative effect on seedling recruitment, particularly for oaks, with largest differences in recruitment between planted and natural forest stands occurring mostly at low fire frequency values (Fig. 3d).

\section{Woody species richness patterns}

Planted forest stands had on average lower species richness than natural forest stands (Table S3). Forest type was the second most important factor in terms of explained deviance for three of the GLM pine species models ( $P$. pinaster, $P$. nigra and P. sylvestris; Table 3 ). Only climatic factors explained a larger proportion of deviance than forest type in the richness models. Species richness was also strongly affected by soil factors ( $\mathrm{pH}$ and texture), monospecific character, coefficient of variation of tree diameter and fire frequency (Table 3 ).

We detected significant interactions between forest type and several of the abiotic, biotic and anthropic variables analysed. The interactions that consistently explained a larger proportion of the deviance for most pine species were those with climate variables, tree density, coefficient of variation of tree diameter and fire frequency (Table S4). Species richness usually showed a Gaussian response along the precipitation gradient. The largest richness differences between forest types occurred at intermediate values and decreased towards the extremes of the precipitation gradient (Fig. 4a). The effect of tree density on species richness differed significantly between planted and natural stands of $P$. pinea and $P$. sylvestris (Table S4). Maximum species richness in natural forest stands occurred at intermediate values of tree density (around 1000 trees per ha), where the largest differences in species richness between forests type were also found (Fig. 4b). Species richness for even-sized (i.e. with low values for coefficient of variation of tree diameter) planted forest stands was lower than those observed in natural forest stands, but these differences decreased and even disappeared for uneven-sized stands (Fig. 4c). Fire frequency had a strong negative effect on species richness, especially in natural forest stands, and the largest differences between forest types consistently occurred at low fire frequency values (Fig. 4d).

\section{DISCUSSION}

Iberian planted pine forests occurred on average on sites which differed in climatic conditions, soils and perturbation regimes with respect to natural pine forests. Planted stands exhibited a 
Table 2 Best models of pine and oak recruitment in forest stands of the five pine species studied. The selected transformation (poly (2) is polynomial transformation of order 2), degrees of freedom (d.f.), model deviance (M. Dev.), explanatory variable deviance (Dev.) and probabilities of chi-square tests of the variable effects are given.

\begin{tabular}{|c|c|c|c|c|c|c|c|c|c|c|c|c|c|c|c|c|c|c|}
\hline & \multicolumn{6}{|c|}{ Pinus halepensis } & \multicolumn{6}{|c|}{ Pinus pinea } & \multicolumn{6}{|c|}{ Pinus pinaster } \\
\hline & \multicolumn{3}{|c|}{$\begin{array}{l}\text { P. seed. } \\
\text { (M. Dev.: 0.06) }\end{array}$} & \multicolumn{3}{|c|}{$\begin{array}{l}\text { Q. seed. } \\
\text { (M. Dev.: 0.29) }\end{array}$} & \multicolumn{3}{|c|}{$\begin{array}{l}\text { P. seed. } \\
\text { (M. Dev.: 0.16) }\end{array}$} & \multicolumn{3}{|c|}{$\begin{array}{l}\text { Q. seed. } \\
\text { (M. Dev.: 0.12) }\end{array}$} & \multicolumn{3}{|c|}{$\begin{array}{l}\text { P. seed. } \\
\text { (M. Dev.: 0.11) }\end{array}$} & \multicolumn{3}{|c|}{$\begin{array}{l}\text { Q. seed. } \\
\text { (M. Dev.: 0.06) }\end{array}$} \\
\hline & d. & Dev. & $P\left(\chi^{2}\right)$ & d.f. & Dev. & $P\left(\chi^{2}\right)$ & d.f & Dev. & $P\left(\chi^{2}\right)$ & d.f & Dev. & $P\left(\chi^{2}\right)$ & d.f. & Dev. & $P\left(\chi^{2}\right)$ & d.f & Dev. & $P\left(\chi^{2}\right)$ \\
\hline Forest type & 1 & 94.7 & $7<\mathbf{0 . 0 0 0 1}$ & & & & 1 & 2.34 & 0.1259 & 1 & 33.14 & $t<0.0001$ & 1 & 53.9 & $<0.0001$ & 1 & 6.8 & 0.0091 \\
\hline Temperature poly (2) & & & & 2 & 581. & $4<\mathbf{0 . 0 0 0 1}$ & 2 & 157.13 & $<0.0001$ & 2 & 100.2 & $<0.0001$ & 2 & 104.1 & $<0.0001$ & 2 & 4.0 & 0.1361 \\
\hline Precipitation poly (2) & 2 & 193 & $<0.0001$ & 2 & 1207. & $<0.0001$ & 2 & 15.03 & $<0.0001$ & & & & 2 & 39 & $<0.0001$ & 2 & 49.6 & $<0.0001$ \\
\hline Soil rockiness & 2 & 45 & $<0.0001$ & 2 & 98. & $<0.0001$ & 2 & 5.82 & 0.0544 & 2 & 22.6 & $<0.0001$ & 2 & 47.1 & $<0.0001$ & 2 & 5.7 & 0.0583 \\
\hline Soil texture & 2 & 10.1 & 0.0063 & 2 & 3. & 0.1583 & & & & 2 & 32.36 & $<<0.0001$ & 2 & 44.1 & $<0.0001$ & 2 & 62.5 & $<0.0001$ \\
\hline Soil pH & 2 & 9.6 & 0.0071 & 2 & 27 & $<0.0001$ & 2 & & & 2 & 1.19 & 0.5508 & & 52.1 & $<0.0001$ & 2 & 8.0 & 0.0187 \\
\hline Basal area poly (2) & 2 & 52.3 & $3<0.0001$ & 2 & 231. & $<0.0001$ & 2 & 26.01 & $<0.0001$ & & & & 2 & 54 & $<0.0001$ & 2 & 38.1 & $<0.0001$ \\
\hline Tree dens. poly (2) & 2 & 10 & 0.0019 & 2 & 8. & $\quad 0.0145$ & 52 & 92.51 & $<0.0001$ & 2 & 43.3 & $<0.0001$ & & & & 2 & 42.2 & $<0.0001$ \\
\hline CVd poly (2) & 2 & 17.3 & $\begin{array}{ll}3 & 0.0003\end{array}$ & 2 & 142 & $<0.0001$ & & & & 2 & 7.08 & 0.0290 & 2 & 122 & $<0.0001$ & 2 & 109 & $<0.0001$ \\
\hline Monosp. poly (2) & 2 & 84.8 & $8<\mathbf{0 . 0 0 0 1}$ & 2 & 303. & $4<\mathbf{0 . 0 0 0 1}$ & & 24.62 & $<0.0001$ & & & & 2 & 545.7 & $7<\mathbf{0 . 0 0 0 1}$ & 2 & 73.4 & $<0.0001$ \\
\hline Dist. Quercus poly (2) & & & & 2 & 138 & $<0.0001$ & & & & 2 & 40.22 & $2<0.0001$ & & & & 2 & 94.1 & $<0.0001$ \\
\hline Nat. mor. poly (2) & 2 & 17.6 & $6<\mathbf{0 . 0 0 0 1}$ & 2 & 12 & 0.0018 & 32 & 9.74 & 0.1091 & & & & 2 & 7.5 & 0.0235 & 2 & 24.9 & $<0.0001$ \\
\hline Ant. mor. poly (2) & 2 & 14.5 & $5<\mathbf{0 . 0 0 0 1}$ & 2 & 6. & 0.0460 & 2 & 4.43 & $<0.0001$ & & & & 2 & 104.5 & $<0.0001$ & 2 & 17.8 & 0.0001 \\
\hline Road poly (2) & 2 & 9.9 & $9 \quad \mathbf{0 . 0 0 4 7}$ & & & & 2 & 31.59 & $<0.0001$ & 2 & 32.17 & $<0.0001$ & & & & 2 & 16.1 & 0.0003 \\
\hline Fire poly (2) & 2 & 16.6 & $6<\mathbf{0 . 0 0 0 1}$ & 2 & & $<0.0001$ & 2 & 27.89 & $<0.0001$ & 2 & 18.06 & 0.0001 & & & & 2 & 35.1 & $<0.0001$ \\
\hline \multirow[t]{4}{*}{ Protection } & & & & 1 & 17. & $<<0.0001$ & & & & 1 & 7.08 & 0.0078 & 1 & 8 & 0.0047 & 1 & 0.3 & 0.6055 \\
\hline & \multicolumn{6}{|c|}{ Pinus nigra } & \multicolumn{6}{|c|}{ Pinus sylvestris } & & & & & & \\
\hline & \multicolumn{3}{|c|}{$\begin{array}{l}\text { P. seed. } \\
\text { (M. Dev.: 0.15) }\end{array}$} & \multicolumn{3}{|c|}{$\begin{array}{l}\text { Q. seed. } \\
\text { (M. Dev.: 0.11) }\end{array}$} & \multicolumn{3}{|c|}{$\begin{array}{l}\text { P. seed. } \\
\text { (M. Dev.: 0.09) }\end{array}$} & \multicolumn{3}{|c|}{$\begin{array}{l}\text { Q. seed. } \\
\text { (M. Dev.: 0.19) }\end{array}$} & & & & & & \\
\hline & d. & Dev. & $P\left(\chi^{2}\right)$ & d.f. & Dev. & $P\left(\chi^{2}\right)$ & d.f & Dev. & $P\left(\chi^{2}\right)$ & d.f & Dev. & $P\left(\chi^{2}\right)$ & & & & & & \\
\hline Forest type & 1 & 418 & $<0.0001$ & 1 & 125 & $<0.0001$ & 1 & 240.6 & $<0.0001$ & 1 & 70.2 & $<0.0001$ & & & & & & \\
\hline Temperature poly (2) & 2 & 34.4 & $4<\mathbf{0 . 0 0 0 1}$ & 2 & 263. & $<0.0001$ & 2 & 52.0 & $<0.0001$ & 2 & 1177 & $<0.0001$ & & & & & & \\
\hline Precipitation poly (2) & 2 & 54.6 & $6<\mathbf{0 . 0 0 0 1}$ & 2 & 86. & $<0.0001$ & 2 & 235.1 & $<0.0001$ & 2 & 145.3 & $<0.0001$ & & & & & & \\
\hline Soil rockiness & 2 & 48.5 & $5<\mathbf{0 . 0 0 0 1}$ & 2 & 64 & $<0.0001$ & 2 & 16.8 & 0.0002 & 2 & 23.6 & $<0.0001$ & & & & & & \\
\hline Soil texture & 2 & 1.4 & $4 \quad 0.4889$ & 2 & 4.8 & 0.0902 & & & & 2 & 15.2 & 0.0005 & & & & & & \\
\hline Soil pH & 2 & 21.5 & $5<\mathbf{0 . 0 0 0 1}$ & 2 & 13. & $4 \quad 0.0012$ & & & & 2 & 8.2 & 0.0169 & & & & & & \\
\hline Basal area poly (2) & 2 & 153 & $<0.0001$ & 2 & 44. & $4<\mathbf{0 . 0 0 0 1}$ & 2 & 57.7 & $<0.0001$ & 2 & 14.9 & 0.0006 & & & & & & \\
\hline Tree dens. poly (2) & 2 & 37.3 & $3<0.0001$ & 2 & 61. & $3<0.0001$ & 2 & 23.2 & $<0.0001$ & 2 & 52.6 & $<0.0001$ & & & & & & \\
\hline CVd poly (2) & 2 & 36.1 & $1<0.0001$ & 2 & 35. & $<0.0001$ & & & & 2 & 66.7 & $<0.0001$ & & & & & & \\
\hline Monosp. poly (2) & 2 & 312 & $<0.0001$ & 2 & 49 & $<0.0001$ & & & & 2 & 72.5 & $<0.0001$ & & & & & & \\
\hline Dist. Quercus poly (2) & & & & 2 & 24. & $4<\mathbf{0 . 0 0 0 1}$ & & & & & & & & & & & & \\
\hline Nat. mor. poly (2) & 2 & 30.7 & $7<\mathbf{0 . 0 0 0 1}$ & 2 & 15. & 0.0005 & 52 & 43.2 & $<0.0001$ & 2 & 6.5 & 0.0382 & & & & & & \\
\hline Ant. mor. poly (2) & 2 & 5.8 & $8 \quad 0.0558$ & 2 & 5. & 0.0562 & 2 & 30.0 & $<0.0001$ & & & & & & & & & \\
\hline Road poly (2) & 2 & 9.3 & 0.0094 & 2 & 28 & $5<0.0001$ & & & & 2 & 84.7 & $<0.0001$ & & & & & & \\
\hline Fire poly (2) & 2 & 14.8 & 0.0006 & 2 & 59. & $4<\mathbf{0 . 0 0 0 1}$ & 2 & 43.4 & $<0.0001$ & 2 & 98.2 & $<0.0001$ & & & & & & \\
\hline Protection & & & & & & & & & & 1 & 39.4 & $<0.0001$ & & & & & & \\
\hline
\end{tabular}

Temperature: mean annual temperature; Precipitation: annual precipitation; Basal area: basal area $\left(\mathrm{m}^{2} \mathrm{ha}^{-1}\right)$; Tree dens.: tree density (trees per ha); CVd: coefficient of variation of tree diameter; Monosp.: monospecific character (\%); Dist. Quercus: distance to the nearest Quercus forest (m); Nat. mor.: basal area lost by natural mortality $\left(\mathrm{m}^{2} \mathrm{ha}^{-1}\right)$; Ant. mor.: basal area lost by anthropic mortality $\left(\mathrm{m}^{2} \mathrm{ha}^{-1}\right)$; Road: distance to road ( $\left.\mathrm{m}\right)$; Fire: fire frequency; Protection: protected area. Differences were considered significant at $P\left(\chi^{2}\right)<0.05$ and are marked in bold.

higher tree density, a greater tendency to form even-sized populations, and a lower recruitment and woody species richness than natural stands. Differences between forest types were species-specific, being more pronounced for mountain than for Mediterranean pine species, and varied strongly along the ecological gradients selected. These patterns suggest the need to develop species- and site-specific actions that would enable the reorientation of planted forests towards states that are structurally and functionally more similar to those of natural forests. 

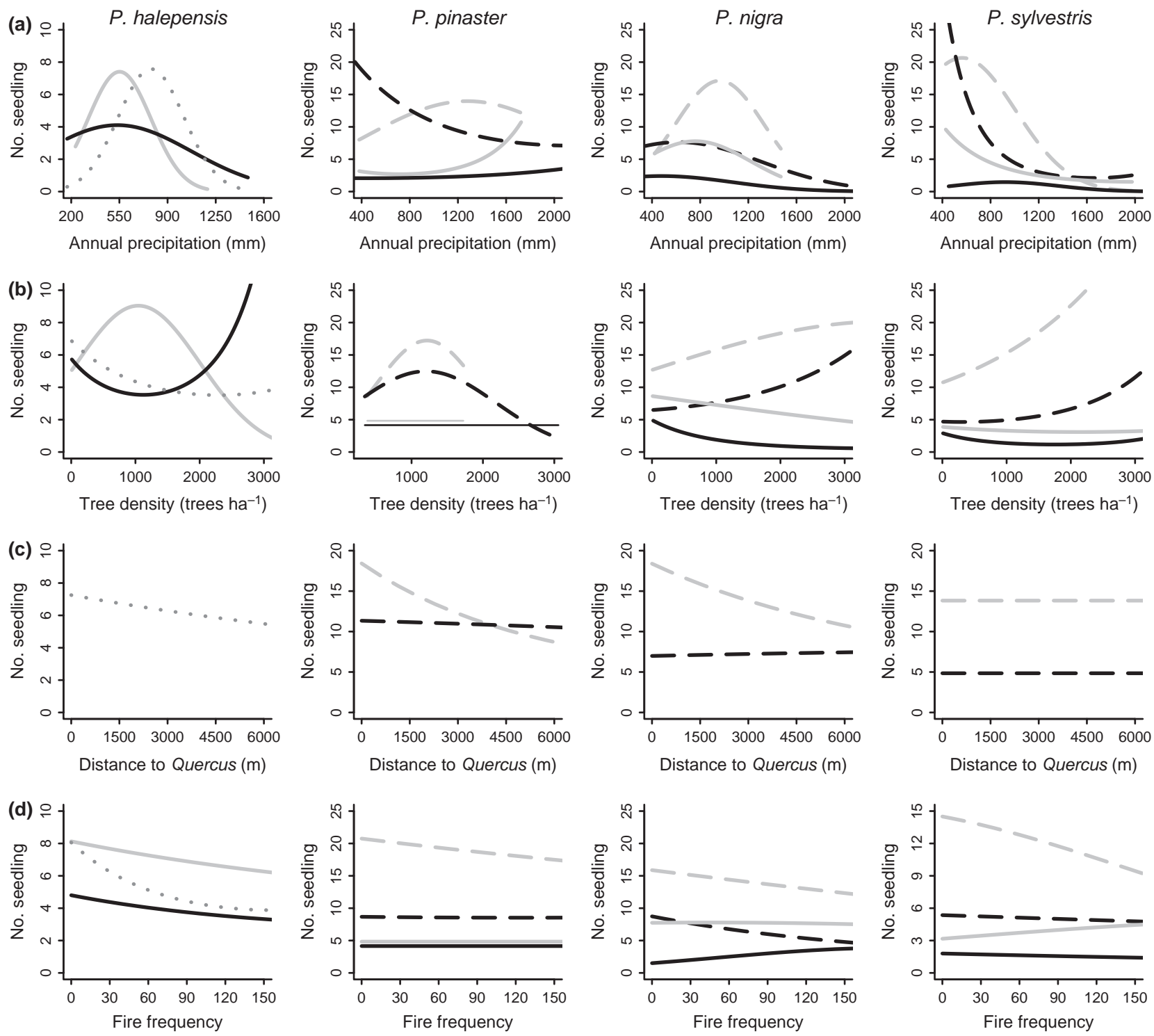

Figure 3 Form of the relationships between predicted pine recruitment (continuous line) and oak recruitment (dashed line) along annual precipitation (a); tree density (b); distance to the nearest Quercus forest (c); and fire frequency (d) in planted (black line) and natural (grey line) forest stands of Pinus halepensis, Pinus pinaster, Pinus nigra and Pinus sylvestris. Pinus pinea was not included in this analysis because forest type had a non-significant effect on pine and oak seedling abundance. Interactions significant between forest type and environmental variables are available in Table S2, and straight lines denote a non-significant effect of the variable on recruitment and are shown in these figures only for comparative purposes. As forest type was not selected by the best generalized linear models of Quercus recruitment in $P$. halepensis stands, a general response curve is shown (grey dotted line).

\section{Environmental and structural characteristics of pine forests}

Differences between the two forest types (planted versus natural) as regards ecological conditions - chiefly climatic, edaphic and disturbance regimes - are both causes and consequences of interacting historical, ecological and sociological factors. Climatic differences between planted and natural stands are probably due in part to the spatial distribution of planted forests (Fig. 1). Species selection in pine plantations was often guided by edapho-climatic suitability models (see Gandullo \& Sánchez-Palomares, 1994), but was also highly influenced by the historical spatial patterns of deforestation and afforestation in the Iberian Peninsula (e.g. Bauer, 1980). Furthermore, the fact that control of erosion was one of the main reasons underlying the reforestation of many degraded areas could explain why some planted pine forests are currently located on poorer soils (rockier and more acidic soils).

The higher intensity of perturbations (anthropic mortality and fire) found in planted with respect to natural pine forests could be related to timber production and structural stand characteristics such as high-density, even-aged structure and horizontal homogeneity (Lloret et al., 2002). Widespread high 
Table 3 Best models of woody species richness in stands of the five pine species studied. The selected transformation (poly (2) is polynomial transformation of order 2), degrees of freedom (d.f.), model deviance (M. Dev.), deviance (Dev.) and probabilities of chi-square tests of the effect of the variable are given.

\begin{tabular}{|c|c|c|c|c|c|c|c|c|c|c|c|c|c|c|c|}
\hline & \multicolumn{3}{|c|}{$\begin{array}{l}\text { Pinus halepensis (M. } \\
\text { Dev.: 0.35) }\end{array}$} & \multicolumn{3}{|c|}{$\begin{array}{l}\text { Pinus pinea (M. Dev.: } \\
0.49 \text { ) }\end{array}$} & \multicolumn{3}{|c|}{$\begin{array}{l}\text { Pinus pinaster (M. } \\
\text { Dev.: } 0.28)\end{array}$} & \multicolumn{3}{|c|}{$\begin{array}{l}\text { Pinus nigra (M. Dev.: } \\
0.36)\end{array}$} & \multicolumn{3}{|c|}{$\begin{array}{l}\text { Pinus sylvestris (M. } \\
\text { Dev.: } 0.51)\end{array}$} \\
\hline & d.f. & Dev. & $P\left(\chi^{2}\right)$ & d.f. & Dev. & $P\left(\chi^{2}\right)$ & d.f. & Dev. & $P\left(\chi^{2}\right)$ & d.f. & Dev. & $P\left(\chi^{2}\right)$ & d.f. & Dev. & $P\left(\chi^{2}\right)$ \\
\hline Forest type & 1 & 1440 & $<0.0001$ & 1 & 105.6 & $<0.0001$ & 1 & 2.3 & 0.1264 & 1 & 516.8 & $<0.0001$ & 1 & 991.3 & $<0.0001$ \\
\hline Temperature poly (2) & 2 & 170.1 & $<0.0001$ & 2 & 727.5 & $<0.0001$ & 2 & 803.2 & $<0.0001$ & 2 & 1448.1 & $<0.0001$ & 2 & 5190.2 & $<0.0001$ \\
\hline Precipitation poly (2) & 2 & 2557.2 & $<0.0001$ & 2 & 680.9 & $<0.0001$ & 2 & 208 & $<0.0001$ & 2 & 197.1 & $<0.0001$ & 2 & 130.1 & $<\mathbf{0 . 0 0 0 1}$ \\
\hline Soil rockiness & 2 & 19.5 & $<0.0001$ & & & & 2 & 232.3 & $<0.0001$ & 2 & 51.1 & $<0.0001$ & 2 & 49.2 & $<0.0001$ \\
\hline Soil texture & 2 & 124.8 & $<0.0001$ & 2 & 136 & $<0.0001$ & 2 & 309.5 & $<0.0001$ & 2 & 24.1 & $<0.0001$ & 2 & 253.2 & $<0.0001$ \\
\hline Soil pH & 2 & 19.9 & $<0.0001$ & 2 & 120.9 & $<0.0001$ & 2 & 293.5 & $<0.0001$ & 2 & 26.1 & $<0.0001$ & 2 & 171.2 & $<0.0001$ \\
\hline Basal area poly (2) & 2 & 57.4 & $<0.0001$ & 2 & 32.5 & $<0.0001$ & 2 & 71.7 & $<0.0001$ & 2 & 67.1 & $<0.0001$ & 2 & 74.1 & $<0.0001$ \\
\hline Tree dens. poly (2) & & & & 2 & 101 & $<0.0001$ & 2 & 98.7 & $<0.0001$ & & & & 2 & 20.3 & $<0.0001$ \\
\hline CVd poly (2) & 2 & 61.3 & $<0.0001$ & 2 & 70.4 & $<0.0001$ & 2 & 246.6 & $<0.0001$ & 2 & 76.7 & $<0.0001$ & 2 & 131.4 & $<0.0001$ \\
\hline Monosp. poly (2) & 2 & 218.3 & $<0.0001$ & 2 & 197 & $<0.0001$ & 2 & 507.2 & $<0.0001$ & 2 & 73.3 & $<0.0001$ & 2 & 249.9 & $<0.0001$ \\
\hline Nat. mor. poly (2) & 2 & 9.1 & 0.0108 & & & & 2 & 7.6 & 0.0226 & & & & 2 & 41.8 & $<0.0001$ \\
\hline Ant. mor. poly (2) & & & & & & & 2 & 4.3 & 0.1176 & & & & & & \\
\hline Road poly (2) & 2 & 59.9 & $<0.0001$ & 2 & 46.5 & $<0.0001$ & 2 & 0.3 & 0.8630 & 2 & 50.3 & $<0.0001$ & 2 & 98.1 & $<\mathbf{0 . 0 0 0 1}$ \\
\hline Fire poly (2) & 2 & 306.2 & $<0.0001$ & 2 & 100.3 & $<0.0001$ & 2 & 90 & $<0.0001$ & 2 & 122.2 & $<0.0001$ & 2 & 138.5 & $<0.0001$ \\
\hline Protection & & & & & & & & & & 1 & 36.3 & $<0.0001$ & & & \\
\hline
\end{tabular}

Temperature: mean annual temperature; Precipitation: annual precipitation; Basal area: basal area $\left(\mathrm{m}^{2}\right.$ ha $\left.{ }^{-1}\right)$; Tree dens.: tree density (trees per ha); CVd: coefficient of variation of tree diameter; Monosp.: monospecific character (\%); Nat. mor.: basal area lost by natural mortality ( $\mathrm{m}^{2}$ ha $\left.{ }^{-1}\right)$; Ant. mor.: basal area lost by anthropic mortality $\left(\mathrm{m}^{2} \mathrm{ha}^{-1}\right)$; Road: distance to road $(\mathrm{m})$; Fire: fire frequency; Protection: protected area. Differences were considered significant at $P\left(\chi^{2}\right)<0.05$ and are marked in bold.

pine stand densities in Spain might be due both to initial planting densities and lack of post-silvicultural operations (Madrigal, 1998). Thus, a combination of edapho-climatic conditions, structural characteristics and disturbance regimes may lead to differences in the patterns of recruitment and woody species richness between the two forest communities.

\section{Seedling recruitment patterns}

In general, pine plantations exhibited lower seedling abundance than natural pine stands, and this effect was more pronounced for oak regeneration. The maximum seedling abundance and the largest differences between forest types were generally found at mesic (medium precipitation) sites, intermediate stand densities, low fire frequencies and in stands closer to Quercus forests.

Oak regeneration is influenced by multiple factors operating at different ontogenetic stages, from fecundity (Espelta et al., 1995; Pérez-Ramos et al., 2010) and seed supply (García et al., 2010) to germination, emergence and establishment of oak seedlings (Gómez et al., 2004; Mendoza et al., 2009). The ecological gradients examined in this study may be interpreted as correlates of underlying mechanisms driving these processes; distance to the nearest Quercus forest with seed supply (Gómez-Aparicio et al., 2009); precipitation and tree density gradients with seed and seedling responses to light and water availability (Rey Benayas et al., 2005; Urbieta et al., 2010); and fire frequency with disturbance regimes (Richardson et al., 2007). Oak recruitment was largely affected by distance to seed sources, especially in Mediterranean pine forests (Table 2), suggesting that the regeneration process is seed limited (e.g. Purves et al., 2007; Zamora et al., 2010). Long-distance dispersal events are crucial for plant colonization and persistence (Cain et al., 2000) and seed arrival at planted forests may be retarded. Firstly, average distances between pine stands and the nearest Quercus forest (Table 1) were much further than the maximum dispersal distance reported for the European jay, Garrulus glandarius, the main disperser of acorns in Mediterranean forests (e.g. Gómez, 2003; Pons \& Pausas, 2007). Moreover, the relatively more homogeneous structure of pine plantations relative to natural stands (Table 1) may lead to a lower avian abundance and thus to a lower seed supply (López \& Moro, 1997; Zamora et al., 2010).

The observed correlation of precipitation and tree density with seedling recruitment - hump-shaped pattern - may reflect various mechanisms associated with resource availability and stress conditions. Specifically, water and light availability exert a critical effect on regeneration in Mediterranean forests (i.e. Marañón et al., 2008; Quero et al., 2011). Seedling establishment can be limited under stressful conditions of both water scarcity (Maestre \& Cortina, 2004) and overabundance (Urbieta et al., 2008). A number of studies have reported optimal conditions for successful oak establishment and growth at intermediate precipitation and stand density values (e.g. Lookingbill \& Zavala, 2000). Specially, oak seed germination and seedling establishment can benefit from partial cover because of water stress reduction (Espelta et al., 1995; Siles et al., 2010). However, at higher densities, light can 

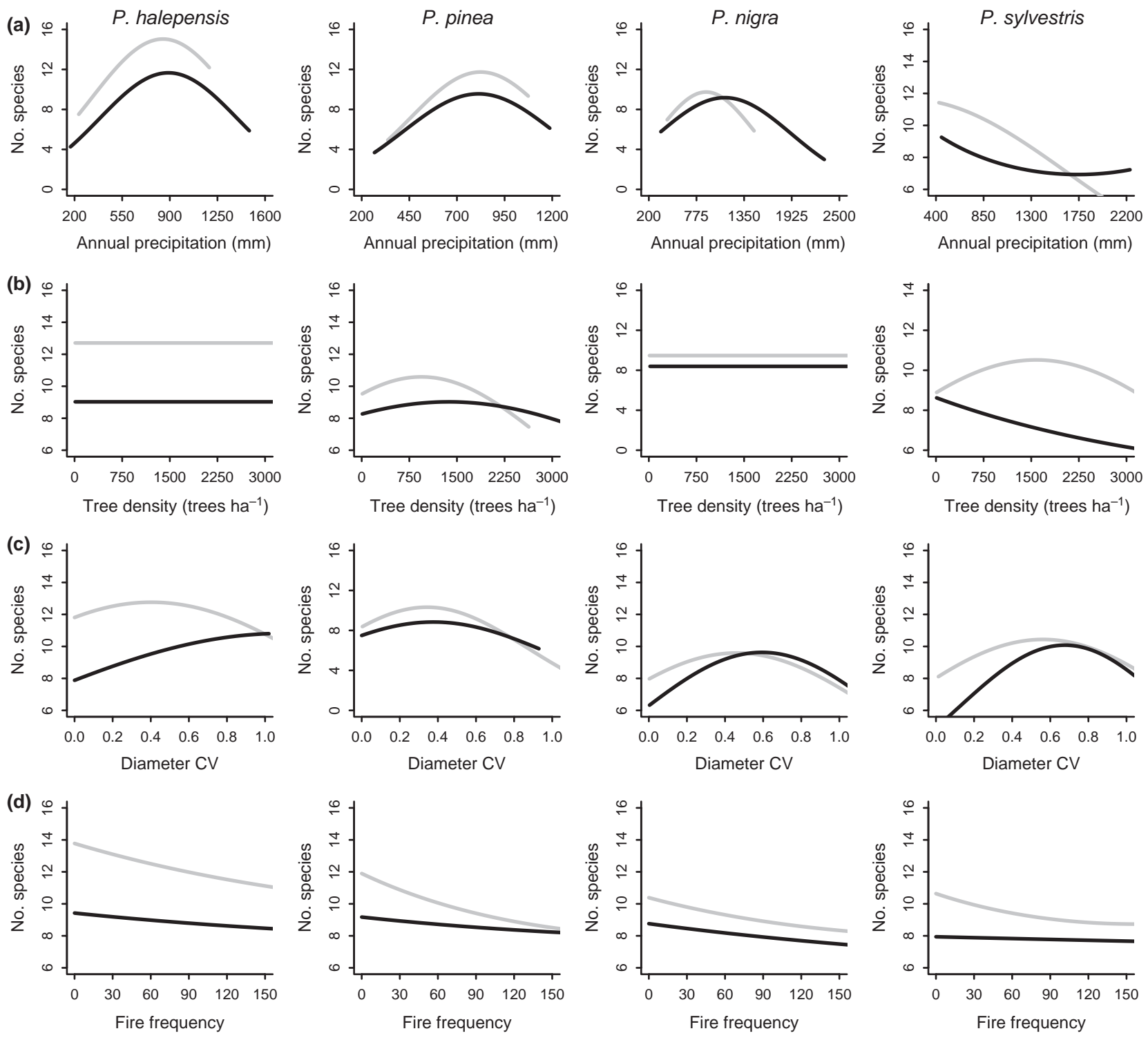

Figure 4 Form of the relationships between predicted woody species richness along annual precipitation (a); tree density (b); coefficient of variation of tree diameter (c); and fire frequency (d) in planted (black line) and natural (grey line) forest stands of Pinus halepensis, Pinus pinea, Pinus nigra and Pinus sylvestris. Pinus pinaster was not considered in this analysis because forest type had a non-significant effect on woody species richness. Interactions significant between forest type and environmental variables are available in Table S2, and straight lines denote a non-significant effect of the variable on recruitment and are shown in these figures only for comparative purposes.

become a limiting factor, inducing a recruitment bottleneck in Mediterranean oak tree species (Zavala et al., 2011). In mountain pine forests, however, a lower productivity (Pausas \& Austin, 2001) and higher understorey light levels may preclude oak mortality under pine stands.

Frequent fires caused a strong decrease in oak seedling abundance, especially pronounced in mountain pine ecosystems (Fig. 3d). The ability of oaks to withstand fires (i.e. through resprouting) is controversial and depends on the frequency and intensity of the fire regime (see López-Soria \& Castell, 1992; Pausas et al., 2008). The decrease in oak recruitment may also be directly linked to the loss of vegetation cover, altering oak seed supply and establishment (García et al., 2010). In spite of the decrease observed in oak seedling abundance, oak recruitment was higher than pine recruitment along the entire fire frequency gradient. Previous studies have reported negative effects of intense and frequent fires on mountain pine recruitment, observed to a lesser extent for oak recruitment (Espelta et al., 2002; Rodrigo et al., 2007).

\section{Woody species richness patterns}

In agreement with Pausas \& Austin (2001), we found that diversity was primarily driven by climate and stand structure, while disturbances played a secondary but important role. Differences in species richness between the two forest types 
were not constant and changed along ecological gradients, being more pronounced in the gradient sections in which natural forests exhibited maximum richness values. Specifically, this pattern was observed for gradients of precipitation, stand structure (tree density and stand evenness) and fire frequency.

Species richness showed a hump-shaped pattern along the precipitation gradient in all stands except those of $P$. sylvestris, where it followed an exponential decay (Fig. 4a). A humpedshaped relationship between species richness and resource availability (e.g. precipitation as a proxy for water availability) has frequently been reported (e.g. Pausas \& Austin, 2001). However, high precipitation levels in Iberian alpine environments are usually related to high elevation and cold areas, which might explain the unusual negative correlation between precipitation and richness observed in P. sylvestris stands (Rey Benayas \& Scheiner, 2002).

Structural complexity promotes diversity through various mechanisms associated with resource variability and habitat heterogeneity (see Carnus et al., 2006; Quilchano et al., 2008). Accordingly, woody species richness followed a hump-shaped relationship with respect to a gradient in structural heterogeneity (i.e. tree density and stand evenness). Other studies have also reported a link between the simplified structure of plantations and their lower levels of plant diversity (Lindenmayer \& Hobbs, 2004; Bremer \& Farley, 2010). It is well known that horizontal and vertical stand heterogeneity have a positive effect on plant species diversity (Halpern \& Spies, 1995; Brockerhoff et al., 2008) and this effect has previously been reported in woody species richness under pine forests (Pausas, 1994). This heterogeneity also influences seed disperser preferences and can therefore contribute to the abundance and composition of the seed rain within the pine plantation (Zamora et al., 2010).

Fire frequency exerted a negative influence on woody species richness with decreasing richness values at higher frequencies for both planted and natural forests. Thus, we did not find support for the Intermediate Disturbance Hypothesis (IDH, Connell, 1978), see Fig. 4, which predicts that maximum species richness occurs at an intermediate level of perturbation. The IDH remains, however, controversial (Miller et al., 2011), and our results agree with Collins et al. (1995), who found a negative relationship between species richness and fire frequency.

\section{Insights for management of Mediterranean planted pine forests}

Our results suggest that some planted pine forests were established beyond the natural climatic range for pine forests in Spain and that the structural characteristics of planted stands differ markedly with respect to natural forests. These differences are translated into lower tree regeneration and woody species diversity along large parts of the environmental gradients explored. Based on our multivariate analyses, we propose a set of priorities to guide current planted pine forests towards a more natural state in areas where recovery of structure and functionality is feasible.

Firstly, we suggest that management activities should target those planted forests that differed from the structure of natural rich pine forests. Specifically, this includes plantations with high tree density, a low coefficient of variation of tree diameter and high monoespecificity. Some of these attributes are a result of initial plantation density, but most result from a lack of post-plantation operations because of socioeconomic factors (Madrigal, 1998). Thinning would be highly recommended in such plantations to increase their structural heterogeneity. A higher structural heterogeneity may in turn reduce recruitment limitation by increasing seed supply (e.g. improving bird abundance, Mendoza et al., 2009; Zamora et al., 2010) and promoting favourable microclimatic conditions that may facilitate oak establishment (i.e. higher light availability and lower water stress, Lookingbill \& Zavala, 2000; Plieninger et al., 2010). Moreover, high monospecificity could contribute to decrease the risk of plantation decline (Moreno-Gutiérrez et al., 2011) and fire occurrence (Lloret et al., 2002; Pausas et al., 2004), and increase forest resilience to climatic changes (e.g. Seppälä et al., 2009).

Secondly, we propose that enrichment planting should be considered as a direct way to enhance regeneration and diversity. Enrichment planting should target plantations located in the parts of the gradients where largest differences in recruitment with respect to natural forests occurred (e.g. intermediate tree density, mesic areas), and that happened to coincide with those parts where maximum recruitment values in natural stands were found. These plantations have the greatest potential for successful recruitment of oak species and successional trajectories towards more natural and diverse mixed forests (Zavala et al., 2000).

Finally, plantations of mountain pines (P. sylvestris and P. nigra) should be prioritized, because they exhibited the strongest divergence in recruitment and diversity with respect to natural pine forests. Moreover, these pine species are particularly vulnerable to potential climatic change (BenitoGarzón et al., 2008; Galiano et al., 2010) and intense fires (Rodrigo et al., 2004; Pausas et al., 2008), which highlights the importance of a quick redirection in management practices to foster resilience.

Pine forests have been present in Iberian landscapes throughout the Holocene, coexisting and alternating with hardwoods and other conifers (e.g. Carrión \& Leroy, 2010). Over the last centuries Euromediterranean countries have undergone dramatic changes, including extensive afforestation, but also more recently agricultural land abandonment (Barbero et al., 1998). This has resulted in a spatially complex successional vegetation framework with multiple pathways determined by ecological conditions, management practices and historical contingencies (e.g. Blondel \& Aronson, 1995). While natural pine forests can be a useful reference system to guide naturalization of planted pine forests, novel successional trajectories are also likely to take place. For example, pine stands from genetic provenances different from local sources 
may exhibit divergent responses along succession or under climate change than locally adapted populations (e.g. BenitoGarzón et al., 2011). Thus, as argued by Hobbs et al. (2006), in addition to a reference system-based approach, further work is needed to revise restoration norms and practices that complement the traditional focus on existing or historical assemblages.

\section{ACKNOWLEDGEMENTS}

This research was supported by INTERBOS3-CGL2008-04503C03-03 (MCI) and SUM2008-00004-C03-01 (INIA) projects. P.R.B. was supported by a FPU fellowship from the Spanish MEC (AP2008-01325). We thank the MARM (Ministerio de Medio Ambiente, Medio Rural y Marino, Dirección General de Medio Natural y Política Forestal) for granting the access to the Spanish Forest Inventory Data and R.A., G.K., J.O., C.N., J.M.R.B. and three anonymous referees for interesting discussions at different stages of this work. Numerical simulations were supported by the SPAS Group at University of Alcala.

\section{REFERENCES}

Alía, R., Alba, N., Agundez, D. \& Iglesias, S. (2005) Manual para la comercialización y producción de semillas y plantas forestales: materiales de base y de reproducción. DGB, Ministerio de Medio Ambiente, Madrid.

Alía, R., García del Barrio, J.M., Iglesias, S., Mancha, J.A., de Miguel, J., Nicolás, J.L., Pérez-Martín, F. \& Sánchez de Ron, D. (2009) Regiones de procedencia de especies forestales en España. DGB, Ministerio de Medio Ambiente, Medio Rural y Marino, Madrid.

Barbero, M., Loisel, R., Quézel, P., Richardson, D.M. \& Romane, F. (1998) Pines of the Mediterranean basin. Ecology and biogeography of Pinus (ed. by D.M. Richardson), pp. 153-170. Cambridge University Press, Cambridge.

Bauer, E. (1980) Los montes de España en la historia. Servicio de Publicaciones Agrarias del Ministerio de Agricultura, Madrid.

Benito-Garzón, M., de Dios, R.S. \& Ollero, H.S. (2008) Effects of climate change on the distribution of Iberian tree species. Applied Vegetation Science, 11, 169-178.

Benito-Garzón, M., Alía, R., Robson, T.M. \& Zavala, M.A. (2011) Intra-specific variability and plasticity influence potential tree species distributions under climate change. Global Ecology and Biogeography, 20, 766-778.

Blanco, E., Casado, M.A., Costa, M., Escribano, R., García, M., Génova, M., Gómez, A., Gómez, F., Moreno, J.C., Morla, C., Regato, P. \& Sáinz, H. (1997) Los bosques ibéricos: una interpretación geobotánica. Editorial Planeta, Barcelona.

Blondel, J. \& Aronson, J. (1995) Biodiversity and ecosystem function in the Mediterranean basin: human and non-human determinants. Mediterranean-type ecosystems: the function of biodiversity (ed. by G.W. Davis and D.M. Richardson), pp. 43-119. Ecological Studies, No. 109. Springer-Verlag, Berlin.
Bolker, B. (2008) Ecological models and data in R. Princeton University Press, Princeton, NJ.

Bremer, L. \& Farley, K. (2010) Does plantation forestry restore biodiversity or create green deserts? A synthesis of the effects of land-use transitions on plant species richness. Biodiversity and Conservation, 19, 3893-3915.

Brockerhoff, E.G., Jactel, H., Parrotta, J.A., Quine, C.P. \& Sayer, J. (2008) Plantation forests and biodiversity: oxymoron or opportunity? Biodiversity and Conservation, 17, 925951.

Cain, M.L., Milligan, B.G. \& Strand, A.E. (2000) Long-distance seed dispersal in plant populations. American Journal of Botany, 87, 1217-1227.

Canadell, J.G. \& Raupach, M.R. (2008) Managing forests for climate change mitigation. Science, 320, 1456-1457.

Carnus, J.M., Parrotta, J., Brockerhoff, E., Arbez, M., Jactel, H., Kremer, A., Lamb, D., O’Hara, K. \& Walters, B. (2006) Planted forests and biodiversity. Journal of Forestry, 104, 65-77.

Carrión, J.S. \& Leroy, S.A.G. (2010) Iberian floras through time: land of diversity and survival. Review of Palaeobotany and Palynology, 162, 227-230.

Ceballos, L. (1966) Mapa Forestal de España escala 1:400000. Ministerio de Agricultura, Madrid.

Chazdon, R.L. (2008) Beyond deforestation: restoring forests and ecosystem services on degraded lands. Science, 320, $1458-1460$.

Chirino, E., Bonet, A., Bellot, J. \& Sánchez, J.R. (2006) Effects of 30-year-old Aleppo pine plantations on runoff, soil erosion, and plant diversity in a semi-arid landscape in south eastern Spain. CATENA, 65, 19-29.

Collins, S.L., Glenn, S.M. \& Gibson, D.J. (1995) Experimental analysis of intermediate disturbance and initial floristic composition: decoupling cause and effect. Ecology, 76, 486492.

Connell, J.H. (1978) Diversity in tropical rain forests and coral reefs. Science, 199, 1302-1310.

Dale, V.H., Joyce, L.A., McNulty, S., Neilson, R.P., Ayres, M.P., Flannigan, M.D., Hanson, P.J., Irland, L.C., Lugo, A.E., Peterson, C.J., Simberloff, D., Swanson, F.J., Stocks, B.J. \& Wotton, B.M. (2001) Climate change and forest disturbances. BioScience, 51, 723-734.

Dudley, N. (2005) Identifying and using reference landscapes for restoration. Forest restoration in landscapes: beyond planting trees (ed. by S. Mansourian, D. Vallauri and N. Dudley), pp. 109-114. Springer, New York.

Espelta, J.M., Riba, M. \& Retana, J. (1995) Patterns of seedling recruitment in West-Mediterranean Quercus ilex forest influenced by canopy development. Journal of Vegetation Science, 6, 465-472.

Espelta, J.M., Rodrigo, A., Habrouk, A., Meghelli, J.L., Ordoñez, J.L. \& Retana, J. (2002) Land use changes, natural regeneration patterns, and restoration practices after large wildfire in NE Spain: challenges for fire ecology and landscape restoration. Fire and biological process (ed. by L. Trabaud and R. Prodon), pp. 315-324. Backyus Publishers, Leinden. 
Evans, J. (2009) Planted forests: uses, impacts and sustainability. Food and Agriculture Organization of the United Nations and $\mathrm{CAB}$ International, Rome.

FAO (2006) Global planted forests thematic study. Results and analysis. Food and Agriculture Organization of the United Nations, Rome.

FAO (2010) Global forest resource assessment 2010. Food and Agriculture Organization of the United Nations, Rome.

Felton, A., Knight, E., Wood, J., Zammit, C. \& Lindenmayer, D. (2010) A meta-analysis of fauna and flora species richness and abundance in plantations and pasture lands. Biological Conservation, 143, 545-554.

Galiano, L., Martínez-Vilalta, J. \& Lloret, F. (2010) Droughtinduced multifactor decline of Scots pine in the Pyrenees and potential vegetation change by the expansion of co-occurring oak species. Ecosystems, 13, 978-991.

Gandullo, J.M. \& Sánchez-Palomares, O. (1994) Estaciones ecológicas de los pinares españoles. Instituto Nacional para la Conservación de la Naturaleza, ICONA, Ministerio de Agricultura, Pesca y Alimentación, Madrid.

García, D., Zamora, R. \& Amico, G.C. (2010) Birds as suppliers of seed dispersal in temperate ecosystems: conservation guidelines from real-world landscapes. Conservation Biology, 24, 1070-1079.

Gómez, J.M. (2003) Spatial patterns in long-distance dispersal of Quercus ilex acorns by jays in a heterogeneous landscape. Ecography, 26, 573-584.

Gómez, J.M., Valladares, F. \& Puerta-Piñero, C. (2004) Differences between structural and functional environmental heterogeneity caused by seed dispersal. Functional Ecology, 18, 787-792.

Gómez-Aparicio, L., Zavala, M.A., Bonet, F.J. \& Zamora, R. (2009) Are pine plantations valid tools for restoring Mediterranean forests? An assessment along abiotic and biotic gradients. Ecological Applications, 19, 2124-2141.

Gonzalo, J. (2008) Diagnosis fitoclimática de la España peninsular. Actualización y análisis geoestadístico aplicado. Universidad Politécnica de Madrid, Escuela Técnica Superior de Ingenieros de Montes, Madrid.

Halpern, C.B. \& Spies, T.A. (1995) Plant-species diversity in natural and managed forest of the Pacific-Northwest. Ecological Applications, 5, 913-934.

Hobbs, R.J., Arico, S., Aronson, J., Baron, J.S., Bridgewater, P., Cramer, V.A., Epstein, P.R., Ewel, J.J., Klink, C.A., Lugo, A.E., Norton, D., Ojima, D., Richardson, D.M., Sanderson, E.W., Valladares, F., Vila, M., Zamora, R. \& Zobel, M. (2006) Novel ecosystems: theoretical and management aspects of the new ecological world order. Global Ecology and Biogeography, 15, 1-7.

Jackson, R.B., Jobbagy, E.G., Avissar, R., Roy, S.B., Barrett, D.J., Cook, C.W., Farley, K.A., le Maitre, D.C., McCarl, B.A. \& Murray, B.C. (2005) Trading water for carbon with biological sequestration. Science, 310, 1944-1947.

Kunstler, G., Thuiller, W., Curt, T., Bouchaud, M., Jouvie, R., Deruette, F. \& Lepart, J. (2007) Fagus sylvatica L. recruitment across a fragmented Mediterranean landscape, importance of long distance effective dispersal, abiotic conditions and biotic interactions. Diversity and Distributions, 13, 799-807. Lamb, D., Erskine, P.D. \& Parrotta, J.A. (2005) Restoration of degraded tropical forest landscapes. Science, 310, 1628-1632.

Lindenmayer, D.B. \& Hobbs, R.J. (2004) Fauna conservation in Australian plantation forests - a review. Biological Conservation, 119, 151-168.

Lloret, F., Calvo, E., Pons, X. \& Díaz-Delgado, R. (2002) Wildfires and landscape patterns in the Eastern Iberian Peninsula. Landscape Ecology, 17, 745-759.

Lookingbill, T. \& Zavala, M. (2000) Spatial pattern of Quercus ilex and Quercus pubescens recruitment in Pinus halepensis dominated woodlands. Journal of Vegetation Science, 11, 607-612.

López, G. \& Moro, M.J. (1997) Birds of Aleppo pine plantations in South-East Spain in relation to vegetation composition and structure. Journal of Applied Ecology, 34, 12571272.

López-Soria, L. \& Castell, C. (1992) Comparative genet survival after fire in woody Mediterranean species. Oecologia, 91, 493-499.

Lugo, A.E. (1992) Comparison of Tropical tree plantations with secondary forest of similar age. Ecological Monographs, 62, 1-41.

Madrigal, A. (1998) Problemática de la ordenación de masas artificiales en España. Cuadernos de la Sociedad Española de Ciencias Forestales, 6, 13-20.

Maestre, F.T. \& Cortina, J. (2004) Are Pinus halepensis plantations useful as a restoration tool in semiarid Mediterranean areas? Forest Ecology and Management, 198, 303-317.

Mansourian, S. (2005) Practical intervention that will support restoration in broad-scale conservation based on WWF experiences. Forest restoration in landscapes: beyond planting trees (ed. by S. Mansourian, D. Vallauri and N. Dudley), pp. 136-142. Springer, New York.

Marañón, T., Camarero, J.J., Castro, J., Díaz, M., Espelta, J.M., Hampe, A., Jordano, P., Valladares, F., Verdú, M. \& Zamora, R. (2008) Heterogeneidad ambiental y nicho de regeneración. Ecología del bosque Mediterráneo en un mundo cambiante (ed. by F. Valladares), pp. 71-102. Ministerio de Medio Ambiente, Madrid.

Mendoza, I., Gómez-Aparicio, L., Zamora, R. \& Matías, L. (2009) Recruitment limitation of forest communities in a degraded Mediterranean landscape. Journal of Vegetation Science, 20, 367-376.

Millennium Ecosystem Assessment (2005) Ecosystem and human well-being: biodiversity synthesis. World Resources Institute, Washington DC.

Miller, A.D., Roxburgh, S.H. \& Shea, K. (2011) How frequency and intensity shape diversity-disturbance relationships. Proceedings of the National Academy of Sciences USA, 108, 5643-5648.

Montero, M. (1997) Breve descripción del proceso repoblador en España (1940-1995). Legno Celulosa Carta, 4, 35-42.

Moreno-Gutiérrez, C., Barberá, G.G., Nicolás, E., De Luis, M., Castillo, V.M., Martínez-Fernández, F. \& Quejereta, J.I. 
(2011) Leaf $\delta^{18} \mathrm{O}$ of remaining trees is affected by thinning intensity in a semiarid pine forest. Plant, Cell \& Environment, 34, 1009-1019.

Oksanen, J., Blanchet, F.G., Kindt, R., Legendre, P., O'Hara, R.G., Simpson, G.L., Solymos, P., Henry, M., Stevens, H. \& Wagner, H. (2010) Vegan: community ecology package. Rpackage version 1.17-0. Available at: http://CRAN.R-project. org/package $=$ vegan (accessed 10 May 2010).

Paquette, A. \& Messier, C. (2010) The role of plantations in managing the world's forests in the Anthropocene. Frontiers in Ecology and the Environment, 8, 27-34.

Pausas, J.G. (1994) Species richness patterns in the understory of Pyrenean Pinus sylvestris forest. Journal of Vegetation Science, 5, 517-524.

Pausas, J.G. \& Austin, M.P. (2001) Patterns of plant species richness in relation to different environments: an appraisal. Journal of Vegetation Science, 12, 153-166.

Pausas, J.G., Blade, C., Valdecantos, A., Seva, J.P., Fuentes, D., Alloza, J.A., Vilagrosa, A., Bautista, S., Cortina, J. \& Vallejo, R. (2004) Pines and oaks in the restoration of Mediterranean landscapes of Spain: new perspectives for an old practice - a review. Plant Ecology, 171, 209-220.

Pausas, J.C., Llovet, J., Rodrigo, A. \& Vallejo, R. (2008) Are wildfires a disaster in the Mediterranean basin? A review. International Journal of Wildland Fire, 17, 713-723.

Pérez-Ramos, I.M., Ourcival, J.M., Limousin, J.M. \& Rambal, S. (2010) Mast seeding under increasing drought: results from a long-term data set and from a rainfall exclusion experiment. Ecology, 91, 3057-3068.

Plieninger, T., Rolo, V. \& Moreno, G. (2010) Large-scale patterns of Quercus ilex, Quercus suber and Quercus pyrenaica regeneration in central-western Spain. Ecosystems, 13, 644660.

Pons, J. \& Pausas, J.G. (2007) Acorn dispersal estimated by radio-tracking. Oecologia, 153, 903-911.

Purves, D.W., Zavala, M.A., Ogle, K., Prieto, F. \& Rey Benayas, J.M. (2007) Environmental heterogeneity, bird-mediated directed dispersal and oak woodland dynamics in Mediterranean Spain. Ecological Monographs, 77, 77-97.

Quero, J.L., Herrero, A. \& Zamora, R. (2011) Linking stochasticity to determinism of woody plant recruitment in a mosaic landscape: a spatially explicit approach. Basic and Applied Ecology, 12, 161-171.

Quilchano, C., Pérez-Ramos, I., Marañón, T., Noejovich, L., Valladares, F. \& Zavala, M.A. (2008) Patterns and ecological consequences of abiotic heterogeneity in managed cork oak forests of Southern Spain. Ecological Research, 23, 127139.

R Development Core Team (2009) R: a language and environment for statistical computing. R Foundation for Statistical Computing, Vienna. Available at: http://www.r-project.org (accessed 10 May 2010).

Rey Benayas, J.M. (2005) Restoring forests after land abandonment. Forests restoration in landscapes: beyond planting trees (ed. by S. Mansourian, D. Vallauri and N. Dudley), pp. 356-360. Springer, New York.
Rey Benayas, J.M. \& Scheiner, S.M. (2002) Plant diversity, biogeography and environment in Iberia: patterns and possible causal factors. Journal of Vegetation Science, 13, 245258.

Rey Benayas, J.M., Navarro, J., Espigares, T., Nicolau, J. \& Zavala, M.A. (2005) Limiting effects of high radiation and weed competition on reforestation of Mediterranean abandoned cropland with contrasting Quercus species. Forest Ecology and Management, 212, 302-314.

Rey Benayas, J.M., Newton, A.C., Diaz, A. \& Bullock, J.M. (2009) Enhancement of biodiversity and ecosystem services by ecological restoration: a meta-analysis. Science, 325, 11211124 .

Richardson, D.M., Rundel, P.W., Jackson, S.T., Teskey, R.O., Aronson, J., Bytnerowicz, A., Wingfield, M.J. \& Procheş, A. (2007) Human impacts in pine forests: past, present, and future. Annual Review of Ecology, Evolution, and Systematics, 38, 275-297.

Rodrigo, A., Retana, J. \& Pico, F.X. (2004) Direct regeneration is not the only response of Mediterranean forests to large fires. Ecology, 85, 716-729.

Rodrigo, A., Quintana, V. \& Retana, J. (2007) Fire reduces Pinus pinea distribution in the northeastern Iberian Peninsula. Ecoscience, 14, 23-30.

Seppälä, R., Buck, A. \& Katila, P. (2009) Adaptation of forest and people to climatic change: a global assessment report. IUFRO, Heksinki.

Siles, G., Rey, P.J. \& Alcántara, J.M. (2010) Post-fire restoration of Mediterranean forests: testing assembly rules mediated by facilitation. Basic and Applied Ecology, 11, 422-431.

Stephens, S.S. \& Wagner, M.R. (2007) Forest plantations and biodiversity: a fresh perspective. Journal of Forestry, 105, 307-313.

Sutton, W.R.J. (1999) The need for planted forests and the example of radiata pine. New Forests, 17, 95-109.

Thornthwaite, C.W. (1948) An approach toward a rational classification of climate. Geographical Review, 38, 55-94.

UNEP (1997) World atlas of desertification, 2nd edn. Edwards Arnold, London.

Urbieta, I.R., Pérez-Ramos, I.M., Zavala, M.A., Marañón, T. \& Kobe, R.K. (2008) Soil water content and emergence time control seedling establishment in three co-occurring Mediterranean oak species. Canadian Journal of Forest Research, 38, 2382-2393.

Urbieta, I., García, L., Zavala, M.A. \& Marañón, T. (2010) Mediterranean pine and oak distribution in the southern of Spain: is there a mismatch between regeneration and adult distributions? Journal Vegetation of Science, 22, 18-31.

Venables, W.N. \& Ripley, B.D. (2002) Modern applied statistics with S. Springer, New York.

Villaescusa, R. \& Díaz, R. (1998) Segundo inventario forestal nacional (1986-1996). Ministerio de Medio Ambiente, ICONA, Madrid.

Zamora, R., Hódar, J.A., Matías, L. \& Mendoza, I. (2010) Positive adjacency effects mediated by seed disperser birds in pine plantations. Ecological Applications, 20, 1053-1060. 
Zavala, M.A. \& Zea, E. (2004) Mechanisms maintaining biodiversity in Mediterranean pine-oak forests: insights from a spatial simulation model. Plant Ecology, 171, 197-207.

Zavala, M.A., Espelta, J.M. \& Retana, J. (2000) Constraints and trade-offs in Mediterranean plant communities: the case of holm oak-Aleppo pine forests. Botanical Review, 66, 119-149.

Zavala, M.A., Espelta, J.M., Caspersen, J.P. \& Retana, J. (2011) Interspecific differences in sapling performance with respect. to light and aridity gradients in Mediterranean pine-oak forests: implications for species coexistence. Canadian Journal of Forest Research, 41, 1432-1444.

\section{SUPPORTING INFORMATION}

Additional supporting information may be found in the online version of this article:

Table $\$ 1$ Mean values and standard error of Pinis and Quercus seedling abundance for planted and natural forest types of the five pine species studied.

Table $\$ 2$ Interactions between forest type and all other variables included in the best models for Pinus and Quercus seedling abundance.

Table $\$ 3$ Mean values and standard error of woody species richness for planted and natural forest types of the five pine species studied.

Table $\$ 4$ Interactions between forest type and all other variables included in the best model of species richness.

As a service to our authors and readers, this journal provides supporting information supplied by the authors. Such mate- rials are peer-reviewed and may be re-organized for online delivery, but are not copy-edited or typeset. Technical support issues arising from supporting information (other than missing files) should be addressed to the authors.

\section{BIOSKETCHES}

Paloma Ruiz-Benito is conducting her $\mathrm{PhD}$ under the supervision of M.A. Zavala and L. Gomez-Aparicio. She is studying the effects of anthropogenic forces on Mediterranean forests and the implications for their restoration and conservation.

Lorena Gomez-Aparicio is a research scientist at the Institute of Natural Resources and Agrobiology (IRNAS-CSIC) in Sevilla, Spain. Her research focuses on understanding the biotic and envirommental drivers of forest structure and dynamics, particularly the role of plant-plant interactions and plant-soil feedbacks.

Miguel A. Zavala is an associate professor at University of Alcala, Madrid, Spain. His research focuses on the mechanisms driving Mediterranean forest dynamics a wide range of scales and levels of ecological organization, from genetic to regional processes, and the development of models to assess vulnerability and resilience to global change impacts.

Author Contributions: M.A.Z. and L.G.A. conceived this study, P.R.B. and L.G.A carried out the analysis, all authors contributed to the writing of the manuscript. 